\title{
The Impact of Duration of using Superabsorbent Diaper on the Incidence of Urinary Tract Infection in Children
}

Helmi Tri Puji Lestari, Pungky Ardanikusuma and Endy P. Prawirohartono

Department of Child Health, Gadjah Mada University, Dr Sardjito Hospital, Yogyakarta, Indonesia

*Corresponding author: Helmi Tri Puji Lestari, Department of Child Health, Medical School, Gadjah Mada University, Dr Sardjito Hospital, JI Kesehatan 1, Yogyakarta, Indonesia, Tel: +62-274-587333; Fax: +62-274-589309; E-mail: helmitri@gmail.com

Received date: June 17, 2014, Accepted date: July 10, 2014, Published date: July 15, 2014

Copyright: ( 2014 Lestari $\mathrm{H}$, et al. This is an open-access article distributed under the terms of the Creative Commons Attribution License, which permits unrestricted use, distribution, and reproduction in any medium, provided the original author and source are credited.

\begin{abstract}
Background: UTI is a common infection in children. Its highest prevalence takes place during infancy and toilet training period in which most infants use diaper. However, the impact of diaper use on UTI in children has been conflicting.
\end{abstract}

Objective: To determine the correlation between duration of superabsorbent diaper usage with incidence of UTI in children.

Methods: We performed a prospective cohort study from August-September 2011. We recruited children who used diaper every day, went to play group or posyandu (community health care centres) at Yogyakarta City. Subjects were divided into 2 groups. We compared the incidence of UTI among children who used a diaper $>4$ hours per day (group I) and those who used a diaper $\leq 4$ hours per day (group II).

Results: There were 180 children included in this study. Out of 90 children in group I, 26 (28.9\%) had UTI whereas $9(10 \%)$ of 90 children from group II had UTI. Multivariate analysis showed that UTI was significantly higher in children who used diaper $>4$ hours per day compared to children who used diaper $\leq 4$ hours per day (OR 3.65; $95 \% \mathrm{Cl} 1.60-8.35)$. The Mantel Haenszel analysis showed that the risk ratio for girls was $3.13(95 \% \mathrm{Cl} 1.50-6.55)$ and boys was $1.56(95 \% \mathrm{Cl} 0.27-8.94)$, use of diaper in girls $>4$ hours per day therefore increased the risk of UTI.

Conclusions: The use of superabsorbent diaper $>4$ hours per day increased the risk of UTI 365 times compared with the use of $\leq 4$ hours per day. Girls who used diaper $>4$ hours per day in girls significantly increased the risk UTI.

Keywords: Superabsorbent diaper; Duration; Risk factor; Urinary tract infection

\section{Introduction}

Urinary tract infection (UTI) is a serious and common infection in children. Its prevalence is $3-5 \%$ in girls and $1 \%$ in boys up to 5 years of age and the highest prevalence takes place during infancy and the toilet training period $[1,2]$. The use of disposable diapers in children becomes a trend nowadays because it is considered to be practical as compared to cloth diaper. Indonesia represents the fourth biggest consumer after China, India and United State of America [3].

Previous studies indicated that the impact of superabsorbent diaper on urinary tract infection has been conflicting [4-6]. Fahimzad et al. reported that superabsorbent diaper was a risk factor of urinary tract infection as compared to standard type. It was presumed that superabsorbent diaper causes less ventilation in genital area than other types of diapers and UTI takes place through ascendant mechanisms as a result of virulent germ colonization in the periurethral area. On the contrary, prior study by Nuutinen et al. indicated that superabsorbent diaper did not increase UTIs in children as compared to standard type diaper and cloth diaper [5].
The contradictory results of the impact of superabsorbent diaper on UTIs in children need further investigation. This study is aimed to determine the correlation between the duration of superabsorbent diaper usage and the incidence of UTI in children.

\section{Methods}

We performed an analytic observational study with a prospective cohort design in Yogyakarta City in the period of August-September 2011. Yogyakarta is one of Indonesia's province that consists of 5 districts. Its population is about 388,627 people and Yogyakarta City has 14 subdistricts. Subjects in this study were drawn using cluster random sampling at 14 subdistricts. The author randomly selected 5 subdistricts. The data of the existing posyandu (community health care centres) and play groups in these areas were collected and letters were sent to them inviting them to take a part in the study. Five Posyandu and 5 playgroups participated in the study.

The inclusion criteria were children, who used superabsorbent diaper every day, going to play groups or visiting a posyandu in Yogyakarta City in study period; who did not receive antibiotics within the last 5 days; whose parents had a telephone or mobile phone, and whose parents signed proxy consents. Exclusion criteria were children who had a UTI on initial screening by dipstick testing and those who 
had anatomic abnormalities and/or urinary tract dysfunction. We used Verify ${ }^{\oplus}$ qualitative dipstick test and confirmed UTI when leukocyte esterase (LE) were positive (equivalent with $70 / \mu \mathrm{L}$ ) or nitrites positive or both showed positive result. We did not perform urine culture for exclusion criteria since urinary dipstick test has a high diagnostic value [7-10].

Subjects that met the inclusion criteria were followed for a week. They were divided into 2 groups: Group I were the children who used superabsorbent diaper more than 4 hours a day and Group II were those who used the diaper less than 4 hours a day. Their mothers or guardians were recalled on the third or fourth day and asked about the use of diaper and reminded to have a second urine dipsticks test. The length of using superabsorbent diaper between the two groups were compared and analyzed with respect to the incidence of UTI.

Educational level of mother was classified into elementary, junior high, senior high school, undergraduate and post graduate based on Act of Republic Indonesia no 20, year 2003 on National Education System. We used 4 hours to divide between two groups of subjects because bacteria need 4 hours to convert nitrat from the diet to nitrit in the urine [7]. Nutritional status was divided into severe malnutrition and not severe malnutrition. Severe malnutrition stated if the body weight for height less than minus three standard deviation based on WHO growth chart [11]. The uses of bubble bath, constipation (based on ROME III criteria for chronic functional constipation for children), breastfeeding status in the first 6 months, circumcision status were nominal scale, divided into yes and no. Type of postmicturition wiping habits on girls divided into back to front, front to back and dabbing [12]. The frequency of diaper changing were divided into rare if less or equal to 4 times per day, often if 4-6 times per day and very often often if more than or equal to 7 times per day 6 .

The data was analyzed using univariate and multivariate analysis with multiple logistic regressions. Significancy was expressed in odds ratios (OR) using a confidence interval (CI) of $95 \%$.

\section{Results}

Three hundred and four patients met the inclusion criteria; 21 had urinary dipsticks analysis indicative of UTI on initial examination and hence were excluded from the study. Two hundred and eighty three enrolled patients were assigned to 2 groups: Group 1 using diaper $>4$ hours a day $(n=180)$ and Group 2 using a diaper for $\leq 4$ hours a day $(n=103)$. They were followed for a week and second urine dipstick test performed at the end of the week. There were 68 subjects in group I and 13 subjects in group II who did not have a second urine test as they were uncooperative or the investigators failed to get a second urine samples. Therefore we had 112 subjects in group I and 90 subjects in group II. We randomized subjects in group I to get minimal sample size of 90 (Figure 1).

The baseline characteristics of the study groups 1 and 2 are shown in Table 1 and included age, sex, origin and mothers' educational level. The mean age of 2-24 months patients was 10 months while the mean age of $>24$ months patients was 2 years and 6 months. The majority of mother's educational levels were senior high school and graduate (S1 or its equivalent).

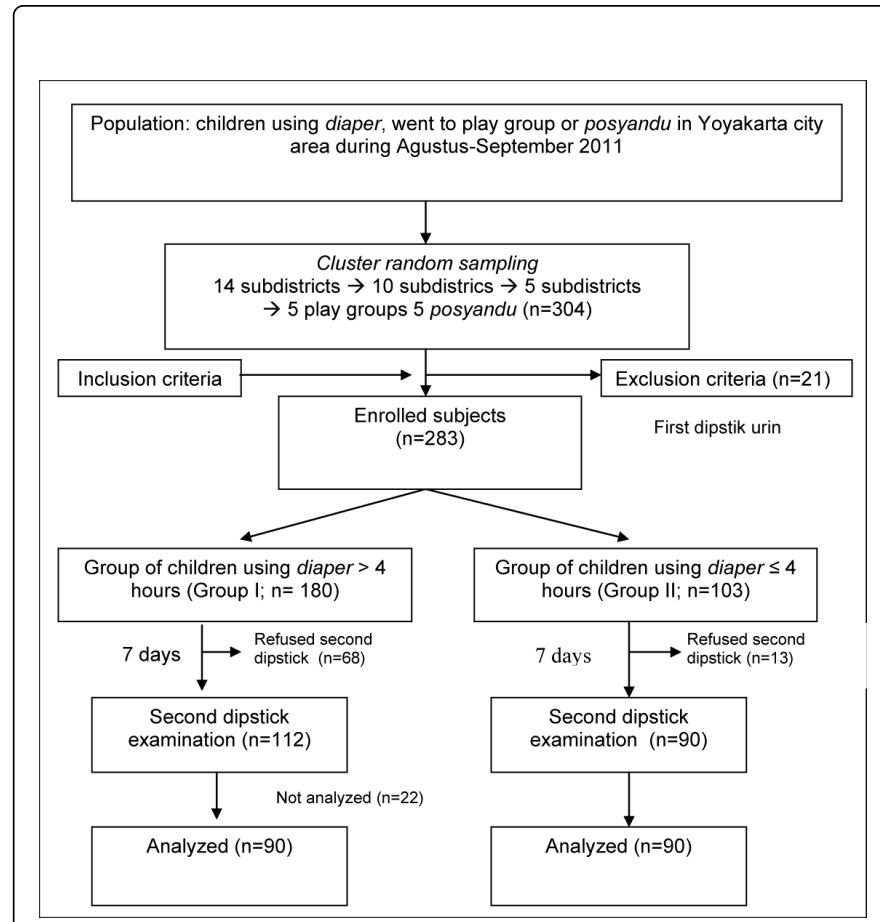

Figure 1: The trial profile

The total prevalence of UTI was $19.4 \%$. There were 26 children (28\%) with UTI in group I and 9 children $(10 \%)$ with UTI in group II. The results of the univariate analysis showed that the daily use of superabsorbent diaper of $>4$ hours increased UTI 2.89 times as compared to the daily use of the diaper of $\leq 4$ hours (OR 2.89; $95 \% \mathrm{CI}$ 1.43-5.81). The mean of duration of using diaper with UTI in group I was 12 hours while group II was 3.7 hours per day.

Age represented as confounding variable. However, the multivariate analysis showed that only duration of using diaper had significant result on the incidence of UTI with $\mathrm{P}=0.02$ and adjusted OR 3.65 (95\%CI 1.60-8.35). Therefore, it could be concluded that the daily use of diapers of $>4$ hours could significantly increase the risk of the UTI as compared to the daily uses of the diapers of $\leq 4$ hours (Table 2).

\begin{tabular}{|l|l|l|}
\hline Characteristics & $>\mathbf{4}$ hours & $\leq 4$ hours \\
\hline Age $\mathbf{n}(\%)$ & & \\
\hline $2-24$ months & $43(47.8)$ & $25(27.8)$ \\
\hline$>24$ months & $47(52.2)$ & $65(72.2)$ \\
\hline Mothers' educational level $\mathbf{n}(\%)$ & & \\
\hline Elementary School & $0(0)$ & $4(4.4)$ \\
\hline Junior High School & $5(5.6)$ & $5(5.6)$ \\
\hline Senior High School & $32(35.6)$ & $51(56.7)$ \\
\hline Graduate (S1 or its equivalent) & $49(54.4)$ & $30(33.3)$ \\
\hline Postgraduate (S2 or its equivalent) & $4(4.4)$ & $0(0)$ \\
\hline Sex n (\%) & & \\
\hline
\end{tabular}


Citation: Helmi Tri Puji Lestari, Pungky Ardanikusuma and Endy P. Prawirohartono (2014) The Impact of Duration of using Superabsorbent Diaper on the Incidence of Urinary Tract Infection in Children. J Nephrol Ther 4: 180. doi:10.4172/2161-0959.1000180

Page 3 of 5

\begin{tabular}{|l|l|l|}
\hline Male & $45(50)$ & $47(52.2)$ \\
\hline Female & $45(50)$ & $43(47.8)$ \\
\hline Subjects' origin $\mathrm{n}(\%)$ & & \\
\hline Posyandu & $21(23.3)$ & $8(8.9)$ \\
\hline Play group & $69(76.7)$ & $82(91.1)$ \\
\hline
\end{tabular}

Table 1: The basic characteristics of the children using superabsorbent diaper

\begin{tabular}{|l|l|l|l|l|l|}
\hline Variable & \multicolumn{2}{|l|}{ Univariate } & \multicolumn{2}{l|}{ Multivariate } \\
\hline & $\mathrm{RR}$ & $95 \% \mathrm{Cl}$ & P value & $\begin{array}{l}\text { OR } \\
\text { (adjusted) }\end{array}$ & $95 \% \mathrm{Cl}$ \\
\hline $\begin{array}{l}\text { The duration of } \\
\text { daily diaper use }> \\
4 \text { hours }\end{array}$ & 2.89 & $1.435-5.814$ & 0.001 & 3.65 & $1.601-8.350$ \\
\hline Age $>24$ months & 1.474 & $0.824-2.634$ & 0.191 & 1.18 & $0.545-2.586$ \\
\hline
\end{tabular}

Table 2: Univariate and multivariate analysis of risk factors of urinary tract infection

Modifier variables were analyzed to find out their impact on the incidence of UTI related to the duration of using diaper (Table 3).

\begin{tabular}{|l|l|l|}
\hline Variable & RR & $\mathbf{9 5 \% ~ C l}$ \\
\hline All $(\mathrm{n}=180)$ & 2.88 & $1.43-5.81$ \\
\hline Boys $(\mathrm{n}=92)$ & 1.56 & $0.27-8.94$ \\
\hline Girls $(\mathrm{n}=88)$ & 3.13 & $1.50-6.55$ \\
\hline Analysis of M-H & 2.80 & $1.43-5.48$ \\
\hline
\end{tabular}

Table 3: The analysis of Mantel Haenszel on sex and the incidence of urinary tract infection related to the duration of using diaper

It could be interpreted that the incidence of the UTI was significantly higher in girls than boys $(\mathrm{p}<0.0001)$ with the daily diaper use of $>4$ hours. The Mantel Haenszel analysis showed that the RR of girls having UTI was 3.13 (95\%CI 1.50-6.55) and boys was 1.56 (95\%CI $0.27-8.94)$. The use of bubble baths, breastfeeding status, constipation, nutritional status, frequency of changing diaper, circumcision status of males, and type of wiping habits of female did not modify the incidence of UTI related to the duration of the daily superabsorbent diaper use.

\begin{tabular}{|l|l|l|l|l|}
\hline Variables & $\begin{array}{l}\text { Duration of } \\
\text { using } \\
\text { diaper }\end{array}$ & UTI (+) & UTI (-) & P value \\
\hline Boys & $\leq 4$ hours & $2(22.2 \%)$ & $45(55.6 \%)$ & - \\
\hline Girls & - & $7(77.8 \%)$ & $36(44.4 \%)$ & 0.058 \\
\hline Boys & $>4$ hours & $3(11.5 \%)$ & $42(65.6 \%)$ & $<0.0001 \#$ \\
\hline Girls & - & $23(88.5 \%)$ & $22(34.4 \%)$ & - \\
\hline Bubble bath (+) & $\leq 4$ hours & $1(11.1 \%)$ & $16(19.8 \%)$ & 1.00 \\
\hline Bubble bath (-) & - & $8(88.9 \%)$ & $65(80.2 \%)$ & - \\
\hline
\end{tabular}

\begin{tabular}{|c|c|c|c|c|}
\hline Bubble bath (+) & $>4$ hours & $8(30.8 \%)$ & $14(21.9 \%)$ & 0.374 \\
\hline Bubble bath (-) & - & $18(69.2 \%)$ & $50(78.1 \%)$ & - \\
\hline $\begin{array}{l}\text { Breastfeeding status } \\
(+)\end{array}$ & $\leq 4$ hours & $8(88.9 \%)$ & $64(79 \%)$ & 0.681 \\
\hline $\begin{array}{l}\text { Breastfeeding status } \\
(-)\end{array}$ & - & $1(11.1 \%)$ & $17(21 \%)$ & - \\
\hline $\begin{array}{l}\text { Breastfeeding status } \\
(+)\end{array}$ & $>4$ hours & $18(69.2 \%)$ & $46(71.9 \%)$ & 0.802 \\
\hline $\begin{array}{l}\text { Breastfeeding status } \\
(-)\end{array}$ & - & $8(30.8 \%)$ & $18(28.1 \%)$ & - \\
\hline Constipation (+) & $\leq 4$ hours & $0(0 \%)$ & $4(4.9 \%)$ & 1.00 \\
\hline Constipation (-) & & $9(100 \%)$ & $77(95.1 \%)$ & \\
\hline Constipation (+) & $>4$ hours & $3(11.5 \%)$ & $4(6.3 \%)$ & 0.407 \\
\hline Constipation (-) & & $23(88.5 \%)$ & $60(93.8 \%)$ & \\
\hline Malnutrition (+) & $\leq 4$ hours & - & - & Constant \\
\hline Malnutrition (-) & & $9(100 \%)$ & $81(100 \%)$ & \\
\hline Malnutrition (+) & $>4$ hours & $0(0 \%)$ & $1(1.6 \%)$ & 1.00 \\
\hline Malnutrition (-) & & $26(100 \%)$ & $63(98.4 \%)$ & \\
\hline $\begin{array}{l}\text { Rare frequency of } \\
\text { changing diaper } * \\
\text { Often frequency of } \\
\text { changing diaper } * * \\
\text { Very often frequency } \\
\text { of changing } \\
\text { diaper } * * *\end{array}$ & $\leq 4$ hours & $\begin{array}{l}9(100 \%) \\
0(0 \%) \\
-\end{array}$ & $\begin{array}{l}80(98.8 \%) \\
1(1.2 \%) \\
-\end{array}$ & 1.00 \\
\hline $\begin{array}{l}\text { Rare frequency of } \\
\text { changing diaper } * \\
\text { Often frequency of } \\
\text { changing diaper } * * \\
\text { Very often frequency } \\
\text { of changing } \\
\text { diaper } * * *\end{array}$ & $>4$ hours & $\begin{array}{l}24(92.3 \%) \\
2(7.7 \%) \\
0(0 \%)\end{array}$ & $\begin{array}{l}50(78.1 \%) \\
10(15.6 \%) \\
4(6.3 \%)\end{array}$ & 0.229 \\
\hline $\begin{array}{l}\text { Back to front wiping } \\
\text { habits } \\
\text { Front to back wiping } \\
\text { habits } \\
\text { Dabbing }\end{array}$ & $\leq 4$ hours & $\begin{array}{l}4(57.1 \%) \\
3(42.9 \%) \\
0(0 \%)\end{array}$ & $\begin{array}{l}8(22.2 \%) \\
27(75 \%) \\
1(2.8 \%)\end{array}$ & 0.163 \\
\hline $\begin{array}{l}\text { Back to front wiping } \\
\text { habits } \\
\text { Front to back wiping } \\
\text { habits } \\
\text { Dabbing }\end{array}$ & $>4$ hours & $\begin{array}{l}10(43.5 \%) \\
11(47.8 \%) \\
2(8.7 \%)\end{array}$ & $\begin{array}{l}8(38.1 \%) \\
12(57.1 \%) \\
1(4.8 \%)\end{array}$ & 0.775 \\
\hline Circumcision (+) & $\leq 4$ hours & - & - & Constant \\
\hline Circumcision (-) & - & $2(100 \%)$ & $45(100 \%)$ & - \\
\hline Circumcision (+) & $>4$ hours & $0(0 \%)$ & $1(2.4 \%)$ & 1.00 \\
\hline Circumcision (-) & - & $3(100 \%)$ & $41(97.6 \%)$ & - \\
\hline
\end{tabular}

Table 4: The Analysis of modifier variables on the incidence of urinary tract infection and the duration of using diaper 
$*$ diaper change $\leq 4$ times a day $* *$ diaper change 4-6 times a day $* * *$ diaper change $\geq 7$ times a day \# significant.

\section{Discussion}

The daily use of superabsorbent diaper for more than 4 hours significantly increased the risk of the UTI as compared to the duration of the daily use of less than 4 hours. Age did not have any significant impact on the incidence of UTI in relation to duration of diaper use. The incidence of the UTI was higher in girls than boys who used diaper for more than 4 hours a day. It can be concluded that the use of diaper more than 4 hours per day increased the risk of UTI especially for girls.

Superabsorbent diaper use SAP (superabsorbent polimer) as the component to absorb urine. This type of diaper resulted in insufficient ventilation in the genital area and incomplete urine evaporation thus providing a source of infection. Colonization of the periurethral area with virulent organisms that access the bladder through ascending route causes UTI [4]. The findings from our study suggested that the daily use of the superabsorbent diaper of $>4$ hours increased the risk of urinary tract infection 3.65 times higher as compared to the daily use of the diaper of $\leq 4$ hours.

The use of bubble bath in previous studies showed that bubble bath is an irritant to the urinary tract of children [13]. The higher number of surfactans in a product influences its irritancy potential. Postmicturition wiping habit on female also influences on the incidence of UTI. Previous study by Persad et al. showed that back to front wiping habit increased the risk of UTI RR 0.72 (95\%CI 0.84-13.78) compared with front to back and dabbing 12. The breastfeeding status in the first 6 months on the incidence of UTI was studied by Martin Sosa et al. Human milk contains of oligosaccharides that inhibit the attachment of Streptococcus pneumonia and E. Coli to host cells. Fucosyloligosaccharide fraction of human milk has been found to protect from the stable toxin of E. Coli and to prevent Campylobacter jejuni attaching to its receptor in human epithelial cells [14]. A fraction of oligosaccharides and glycoconjugates, functioning as receptors analogues for uropathogens, blocking their attachment to the mucosal membranes [15]. However in our study this did not show an increased risk for UTI with longer duration of diaper use.

Nutritional status in a previous study by Bagga et al. showed that the incidence of bacteriuria in malnourished children was significantly increased compared with normally nourished children. No specific factors contributing to UTI in malnutrition have been defined. The increased susceptibility of malnourished children with UTI might be due to breakdown of anatomical barriers; decreased cell mediated immunity, decreased opsonic activity and decreased of phagocytosis of urinary pathogen [16].

The limitation of this study was that the diagnosis of the UTI has not been firmly established using urine culture which is the gold standard, because of time and financial constraints. Urine dipstick test has high sensitivity and specificity for either leukocyte esterase or nitrite and a high positive likelihood ratio, especially for nitrite and combination of leukocyte esterase and nitrite for diagnosis of UTI. It is also practical to use in a field study [7-10]. The diagnosis of the UTI in this study was conducted on the basis of qualitative dipstick test that enabled the emergence of bias because of its subjective nature. Therefore, to avoid the bias the author confirmed positive UTI if the LE dipstick result was positive 1 with the value of $70 / \mu \mathrm{L}$ in which the change in the titer color from white to purple was clearly observed.
Diagnosis of UTI also confirmed if nitrite was positive or both nitrite and LE were positive. Another limitation of this study was that the author did not conduct anatomical screening of subject's urinary tract, which would have possibly significant impact on the UTI in the children. The screening was not conducted because of financial constraints.

The strengths of this study were it use of a cohort prospective design and randomisation which is the highest level of evidence among other designs of the previous published studies on use of diapers. It was conducted at community levels, which were play groups and Posyandu and hence it minimized comorbid diseases that could have significant impact on the incidence of UTI. The urine samples examined were fresh urines and they were directly examined in the location thus minimizing urine contamination.

The results of a prior study by Fahimzad et al. suggesting that superabsorbent diaper increased the risk of the urinary tract infection with OR 3.29 as compared to standard type of diaper.4 Based on the results of the study it was proven that the longer was the duration of the daily use of the superabsorbent diaper (i.e., $>4$ hours), the higher the risk of the urinary tract infection was as indicated by the 3.65 folds increase as compared to the duration of the daily used of the diaper of $<4$ hours. Other study of the impact of the frequency of diaper changing on the urinary tract infection by Sugimura et al. was indicative of a similar result, which showed that the lower the frequency of diaper change (i.e., 4 times a day or less), the higher the risk of the UTI $(\mathrm{P}<0.0001)$ compared to a higher frequency of the diaper changing (7 times a day) [6]. The lower frequency of diaper changing which also means the longer was the diaper was used will make longer contact of urine with the periurethral area. The colonization of virulent bacteria in that area through ascendant route would easily cause the urinary tract infection.

The modifier that had significant impact on the UTI was sex as more girls with the daily use of the diaper of $>4$ hours were developed UTI. The most possible explanation was that the anatomic of female urethra was much shorter than that of males so if the diaper were longer used, the colonization by bacteria in the periurethral area increased as a result of the contact with urine that subsequently caused the UTI via and ascendant route $[17,18]$.

It is necessary to conduct further study to examine the impact of the duration using different type of diapers on the incidence of UTI considering that many cloth types of diapers are nowadays sold in market place, which can be washed and reused (e.g., clodi/cloth diapers).

\section{Acknowledgments}

We are extremely grateful to research assistants Stella, Lenny, Maria, Nafis and Angga for gathering research subjects. We thank SGM staffs and teachers at Taat Insan Mulia PG, Pelangi Anak PG, TSS PG, Kalam Kudus PG, midwife and Posyandu Committee at Pakuncen, Jetisharjo and Tegalrejo.

\section{Declaration}

Researchers declare that there is no conflict of interest.

\section{References}

1. Mårild S, Jodal U (1998) Incidence rate of first-time symptomatic urinary tract infection in children under 6 years of age. Acta Paediatr 87: 549-552. 
Citation: Helmi Tri Puji Lestari, Pungky Ardanikusuma and Endy P. Prawirohartono (2014) The Impact of Duration of using Superabsorbent Diaper on the Incidence of Urinary Tract Infection in Children. J Nephrol Ther 4: 180. doi:10.4172/2161-0959.1000180

Page 5 of 5

2. Larcombe J (2004) Urinary tract infection in children. Clin Evid : 509-523.

3. Richer C (2005) The future of diaper industry. Diaper Consulting Services. Mineapolis.

4. Fahimzad A, Taherian M, Dalirani R, Shamshiri A (2010) Diaper type as a risk factor in urinary tract infection of children. Iran J Pediatr 20: 97-100.

5. Nuutinen M, Huttunen NP, Uhari M (1996) Type of nappy and nursing habits in acquiring acute urinary tract infection. Acta Paediatr 85: 1039-1041.

6. Sugimura T, Tananari Y, Ozaki Y, Maeno Y, Tanaka S, et al. (2009) Association between the frequency of disposable diaper changing and urinary tract infection in infants. Clin Pediatr (Phila) 48: 18-20.

7. Subcommittee on Urinary Tract Infection, Steering Committee on Quality Improvement and Management, Roberts KB (2011) Urinary tract infection: clinical practice guideline for the diagnosis and management of the initial UTI in febrile infants and children 2 to 24 months. Pediatrics 128: 595-610.

8. Whiting P, Westwood M, Watt I, Cooper J, Kleijnen J (2005) Rapid test and urine sampling techniques for the diagnosis of urinary tract infection in children under five years: a systematic review. BMC Pediatrics, 5:4.

9. Williams GJ, Macaskill P, Chan SF, Turner RM, Hodson E, et al. (2010) Absolute and relative accuracy of rapid urine tests for urinary tract infection in children: a meta-analysis. Lancet Infect Dis 10: 240-250.
10. Zorc JJ, Kiddoo DA, Shaw KN (2005) Diagnosis and management of pediatric urinary tract infections. Clin Microbiol Rev 18: 417-422.

11. WHO (2010) Pediatrics pocketgraphs CDC-NCHS growth chart.

12. Persad S, Watermeyer S, Griffiths A, Cherian B, Evans J (2006) Association between urinary tract infection and postmicturition wiping habit. Acta Obstet Gynecol Scand 85: 1395-1396.

13. Modgil G, Baverstock A (2006) Should bubble baths be avoided in children with urinary tract infections? Arch Dis Child 91: 863-865.

14. Martín-Sosa S, Martín MJ, Hueso P (2002) The sialylated fraction of milk oligosaccharides is partially responsible for binding to enterotoxigenic and uropathogenic Escherichia coli human strains. J Nutr 132: 3067-3072.

15. Mårild S, Hansson S, Jodal U, Odén A, Svedberg K (2004) Protective effect of breastfeeding against urinary tract infection. Acta Paediatr 93: 164-168.

16. Bagga A, Tripathi P, Jatana V, Hari P, Kapil A, et al. (2003) Bacteriuria and urinary tract infections in malnourished children. Pediatr Nephrol 18: 366-370.

17. AAP (American Academy of Pediatrics) (2010) Urinary tract infection and vesicoureteral reflux in infants and children. Pediatrics 3: 451-463.

18. Chang SL, Shortliffe LD (2006) Pediatric urinary tract infections. Pediatr Clin North Am 53: 379-400. 